日心第74回大会 (2010)

第2日 9月21日（火） $9: 30 \sim 11: 30$ A301

\title{
WS044 非行少年・犯罪者のパーソナリティを把握する
}

$\begin{array}{lllll}\text { 企 画 者 } & \text { 甲南女子大学 } & \text { 岡本 } & \text { 英生 } \\ \text { 司 会 者 } & \text { 愛知県立大学 } & \text { 堀尾 } & \text { 良弘 } \\ \text { 話題提供者 } & \text { 大阪刑務所 } & \text { 井上 } & \text { 和則\# } \\ \text { 話題提供者 } & \text { 富山少年鑑別所 } & \text { 中島 } & \text { 啓之 } \\ \text { 話題提供者 } & \text { 大阪少年鑑別所 } & \text { 近藤 } & \text { 淳哉 } \\ \text { 指定討論者 } & \text { 高松少年鑑別所 } & \text { 黒澤 } & \text { 良輔 \# }\end{array}$

\section{概 要}

非行少年・犯罪者のパーソナリティを理解することは、個々の非行少年・犯罪者に対してどのようにかか わっていくかという今後の方針を決める上で重要な情報となる。適切な対応を行い、効果的に再犯を防止す るためにも、正確な心理アセスメントが必要である。しかし、非行・犯罪者と一口に言ってもさまざまなパ ーソナリティ特性を持っている上に、多くは拘禁下でアセスメントが実施されることから、特別な工夫が必 要となる。非行少年・犯罪者のパーソナリティの把握に迫る仕事は、心理アセスメントの新しい手法を開発・ 発展させる大きな可能性を持っている。そこで、非行少年や犯罪者の心理アセスメントを実務として行って いる専門家を話題提供者とし、その実際、実施上の諸問題、そして今後の課題などについて検討する。 